\title{
Endogenous dynorphin in emotional control and stress response revisited
}

\author{
Christoph Schwarzer ${ }^{1 *}$, Christian Lutsch', Eduard Schunk', Iris Kastenberger ${ }^{1}$, Herbert Herzog ${ }^{2}$ \\ From 16th Scientific Symposium of the Austrian Pharmacological Society (APHAR) \\ Vienna, Austria. 25-27 November 2010
}

\section{Background}

We recently demonstrated a clearly anxiolytic phenotype of prodynorphin-deficient (dynKO) mice on the C57bl/ $6 \mathrm{~N}$ background. However, other groups observed a less prominent and partially paradigm-dependent anxiogenic phenotype or even anxiogenic phenotype of other dynKO mice. Therefore we backcrossed our dynKO mice onto the balb/c background and evaluated their anxiety-related behaviour.

\section{Methods}

In this study, we investigated anxiety and stress-related behaviour of germ-line prodynorphin knockout (dynKO) mice. Behavioural data were complemented by measurement of corticosterone serum levels.

\section{Results}

Male dynKO mice exhibited about 2-fold ambulation in the open field center and intermediate areas. DynKO mice showed also longer distance travelled (2fold) and more time spent on open arms of the elevated plus maze test. Significantly higher numbers of mice entering the open lit area in the light-dark test were observed in dynKO as compared to wild-type mice. As observed on the C57bl/6N background, only minor changes were observed in the stress-coping abilities measured in the tail suspension and forced swim tests. A reduction of basal corticosterone levels was observed in dyn-KO mice.

\footnotetext{
* Correspondence: schwarzer.christoph@i-med.ac.at

${ }^{1}$ Institute of Pharmacology, Innsbruck Medical University, 6020 Innsbruck, Austria

Full list of author information is available at the end of the article
}

\section{Conclusions}

Taken together our data support the anxiogenic effects of endogenous dynorphin as observed on the C57bl/6N background. However, the phenotype is less clear on the balb/c background.

\section{Acknowledgements}

This project was supported by the Austrian Science Fund (P20107).

\section{Author details}

${ }^{1}$ Institute of Pharmacology, Innsbruck Medical University, 6020 Innsbruck, Austria. ${ }^{2}$ Neuroscience Research Program, Garvan Institute of Medical

Research, Darlinghurst NSW 2010, Australia.

Published: 16 November 2010

doi:10.1186/1471-2210-10-S1-A32

Cite this article as: Schwarzer et al.: Endogenous dynorphin in

emotional control and stress response revisited. BMC Pharmacology 2010 10(Suppl 1):A32.
Submit your next manuscript to BioMed Central and take full advantage of:

- Convenient online submission

- Thorough peer review

- No space constraints or color figure charges

- Immediate publication on acceptance

- Inclusion in PubMed, CAS, Scopus and Google Scholar

- Research which is freely available for redistribution 